\title{
FRACTURE RESISTANCE AND FAILURE PATTERN OF TEETH SUBMITTED TO INTERNAL BLEACHING WITH 37\% CARBAMIDE PEROXIDE, WITH APPLICATION OF DIFFERENT RESTORATIVE PROCEDURES
}

\author{
RESISTÊNCIA À FRATURA E PADRÃO DE FALHA DE DENTES SUBMETIDOS AO CLAREAMENTO \\ INTERNO COM PERÓXIDO DE CARBAMIDA A 37\%, COM APLICAÇÃO DE DIFERENTES \\ PROCEDIMENTOS RESTAURADORES
}

Gerson BONFANTE ${ }^{1}$, Osvaldo Bazzan KAIZER², Luiz Fernando PEGORAROํㅜ, Accácio Lins do VALLE ${ }^{1}$

1- Professor of the Department of Prosthodontics, Bauru Dental School, University of São Paulo.

2- Professor of the Department of Restorative Dentistry, Santa Maria Dental School, Federal University of Santa Maria. PhD student in Oral Rehabilitation at Bauru Dental School, University of São Paulo.

Corresponding address: Osvaldo Bazzan Kaizer - Rua São Gonçalo, 6-73 - Ap. 121 - Cep.: 17015-450, Bauru, SP, Brazil.

Fone: +55 (14) 3226-3061 - e-mail: okaizer2000@yahoo.com.br

Received: July 18, 2005 - Modification: October 20, 2005 - Accepted: July 28, 2006

\begin{abstract}
$O$

bjective. This study investigated the compressive fracture strength and failure pattern in premolars submitted to endodontic treatment and internal bleaching with 37\% carbamide peroxide for 21 days, with application of different restorative procedures. Material and methods. Six groups were employed $(\mathrm{n}=10): 1$ ) non-bleached teeth and pulp chamber sealed with IRM; 2) bleached teeth and pulp chamber sealed with IRM; 3) bleached teeth and pulp chamber filled with light cured composite resin; 4) bleached teeth, root canals prepared at 10mm, filling of the root canal and pulp chamber with IRM; 5) bleached teeth, root canals prepared at 10mm, luting of prefabricated metallic post with zinc phosphate and pulp chamber sealed with composite resin; 6) bleached teeth, root canals prepared at 10mm, luting of glass fiber post with resin cement and pulp chamber sealed with composite resin. After 24-hour storage in distilled water, the specimens were submitted to compressive fracture strength testing in a universal testing machine. Results. The following values were found: Group 1 - 56.23kgf; Group 2 - 48.96kgf; Group 3 - 53.99kgf; Group 4 - 45.72kgf; Group 5 - 54.22kgf; Group 6-60.12kgf. The analysis of variance did not reveal statistically significant difference between groups $(\mathrm{p}<0.05)$, suggesting that internal bleaching with 37\% carbamide peroxide did not weaken the dental tissues. The largest number of unfavorable fractures was observed for Groups 2 (50\%), 4 (40\%), and 5 (30\%). Group 6 exhibited the most favorable failure pattern. Conclusions. The results suggest that internal bleaching with $37 \%$ carbamide peroxide did not significantly weaken the teeth. Among the bleached teeth, those with temporary IRM restorations or metallic posts demonstrated the most unfavorable fracture pattern, whereas the most favorable fracture pattern occurred in teeth restored with composite resin and glass fiber posts.

Uniterms: Post and core; Dental pins; Compressive fracture strength; Tooth bleaching.
\end{abstract}

\begin{abstract}
RESUMO
O

bjetivo. O objetivo do estudo foi investigar a resistência à fratura sob compressão e padrão de falha de pré-molares tratados endodonticamente e clareados internamente por 21 dias com peróxido de carbamida a 37\%, aplicando-se diferentes procedimentos restauradores. Material e métodos. O objetivo deste estudo foi investigar a resistência à fratura sob compressão e padrão de falha de pré-molares unirradiculares tratados endodonticamente e clareados internamente com peróxido de carbamida a 37\%. Foram constituídos 6 grupos $(\mathrm{n}=10)$ : 1) dentes sem clareamento e câmara pulpar vedada com IRM; 2) dentes clareados e câmara pulpar vedada com IRM; 3) dentes clareados e câmara pulpar preenchida com resina composta fotopolimerizável; 4) dentes clareados, condutos preparados com 10mm, e preenchimento do conduto e câmara pulpar com IRM; 5) dentes clareados, condutos preparados com $10 \mathrm{~mm}$, cimentação de pino metálico pré-fabricado com fosfato de zinco e câmara pulpar vedada com resina composta; 6) dentes clareados, condutos preparados com 10mm, cimentação de pino de fibra de vidro com cimento resinoso e câmara pulpar vedada com resina composta. Após 24 horas de armazenamento em água destilada, os espécimes foram submetidos ao teste de resistência à fratura sob compressão em máquina de ensaios universal. Resultados. Os seguintes valores foram encontrados: grupo 1 - 56,23kgf; grupo 2 - 48,96kgf; grupo 3 - 53,99kgf; grupo 4 - 45,72kgf; grupo 5 - 54,22kgf; grupo 6-60,12kgf. A Análise de Variância não mostrou diferença estatisticamente significante entre os grupos ( $<$.05), sugerindo que o clareamento interno com peróxido de carbamida a 37\% não enfraqueceu os tecidos dentais. O maior número de fraturas desfavoráveis foi encontrado nos grupos 2 (50\%), 4 (40\%), e 5 (30\%). O grupo 6 exibiu o padrão de falhas mais favorável. Conclusão. Os resultados sugerem que o clareamento interno com peróxido de carbamida a 37\% não causou enfraquecimento importante dos dentes. Entre os dentes clareados, aqueles com restaurações temporárias de IRM ou com pinos metálicos mostraram o padrão mais desfavorável de fratura, enquanto o padrão de fratura mais favorável ocorreu em dentes restaurados com resina composta e pinos de fibras de vidro. Unitermos: Retentor intra-radicular; Pinos dentários; Força compressiva; Clareamento de dente.
\end{abstract}




\section{INTRODUCTION}

Increasing importance has been currently assigned to facial esthetics. Within this context, white, well-contoured and aligned teeth are considered not only attractive, but also as indicators of nutritional health, self-esteem, good hygiene patterns, economic status and sensuality ${ }^{2}$. However, nearly $10 \%$ of endodontically treated teeth presented shade alterations $^{16}$, due to different causes: pulp hemorrhage, insufficient coronal opening, drugs employed in root canal treatment, filling materials and pulp calcification ${ }^{3,9}$, causing distress to the patients when speaking or smiling.

The bleaching techniques are primarily based on chemical oxidation processes ${ }^{3,6}$, and one of the most employed for non-vital teeth associates sodium perborate with 30\% hydrogen peroxide (superoxol). The carbamide peroxide, according to its concentration (10\%, $16 \%, 35 \%, 37 \%$, etc), is effective for bleaching of vital or non-vital teeth, both for immediate bleaching at the dental office or at home ${ }^{19}$.

Alterations in the tooth structure (porosity, demineralization, reduction in microhardness) $)^{5,20,9,12,18,8,10,23}$ and reduced adhesion of composites to the dentin ${ }^{12,1,26}$ have been associated with oxidizing agents. It is generally agreed that endodontic treatment reduces the fracture strength ${ }^{15}$, yet it is not known whether bleaching causes additional strength reduction.

A study demonstrated that the resistance of teeth bleached with sodium perborate and superoxol was $45 \%$ lower compared to intact teeth and 20\% lower compared to non-bleached teeth with coronal opening ${ }^{13}$, which was confirmed by the follow-up of bleached teeth restored with composite resin and post for 3 to 16 years, which revealed a low incidence of fracture ${ }^{14}$. When dentin was bleached with (1) superoxol; (2) sodium perborate; or (3) sodium perborate mixed with superoxol, the lowest compressive fracture strength of dentin and the lowest hardness were found with isolated utilization of superoxol, and the shear strength of dentin was lower when superoxol was associated with sodium perborate ${ }^{9}$.

The immersion of teeth in $10 \%$ or $16 \%$ carbamide peroxide yielded an increase in porosity and reduction in enamel microhardness after 30 hours $^{5}, 56$ hours $^{20}$ or 241 hours $^{22}$. Immersion for 7 days in 30\% hydrogen peroxide; $10 \%$ to $15 \%$ carbamide peroxide; or sodium perborate led to a reduction in the levels of calcium, phosphate and potassium of teeth; in the enamel, the reduction was higher with superoxol; in the dentin and cement, there was significant reduction with the 3 agents ${ }^{25}$.

Other authors did not observe strength reduction ${ }^{21,27}$ nor clinical or microscopic alterations on the enamel surface of bleached teeth ${ }^{17,11,29}$ with different bleaching agents.

Carious lesions in endodontically treated teeth, either bleached or not, yield a significant reduction in strength, especially when there is loss of marginal ridge ${ }^{24,4}$, and composite resin is the material of choice in these cases, since even though it does not recover all its strength ${ }^{24}$, it restores it in up to $87 \%$, more than glass ionomer ${ }^{3}$; metallic posts did not significantly increase the strength ${ }^{3}$. In another study, the composite resin duplicated the strength in nonbleached teeth and was three times higher in bleached teeth ${ }^{7}$.

The aims of this study were: 1) to evaluate the compressive fracture strength of endodontically treated teeth bleached with 37\% carbamide peroxide for 21 days, with application of different restorative techniques; 2) to evaluate the failure pattern occurring in these teeth after the fracture resistance test.

\section{MATERIALS AND METHODS}

Sixty single-rooted intact premolars were selected, with an average length of $15 \mathrm{~mm}$, cervical diameter of 6.0 to $6.7 \mathrm{~mm}$ in mesiodistal direction and 8.0 to $8,6 \mathrm{~mm}$ in buccolingual direction. The teeth were endodontically treated, fixated in plastic cylinders with acrylic resin, keeping 3mm of the root exposed, and randomly divided into 6 groups (with 10 specimens each), as follows: Group 1) teeth without bleaching and pulp chamber sealed with IRM; Group 2) bleached teeth and pulp chamber sealed with IRM; Group 3) bleached teeth and pulp chamber filled with light cured composite resin; Group 4) bleached teeth, root canals prepared at $10 \mathrm{~mm}$ and filling of the root canal and pulp chamber with IRM; Group 5) bleached teeth, root canals prepared at $10 \mathrm{~mm}$, luting of prefabricated metallic post with zinc phosphate and pulp chamber sealed with composite resin; Group 6) bleached teeth, root canals prepared at $10 \mathrm{~mm}$, glass fiber post luted with resin cement and pulp chamber sealed with composite resin (Figure 1).

In Group 1, the teeth were not bleached and the pulp chamber was filled with zinc oxide-eugenol cement type II (IRM, Dentsply Ind. e Com., Rio de Janeiro, Brazil), to simulate the stage of temporary restoration after endodontic treatment. In all groups, coronal opening was performed with a diamond bur $n .1014$ until occurrence of trepanation, complemented by a diamond bur n. 2082, so as the final size of the coronal opening was $2.5 \mathrm{~mm}$ both in buccolingual and mesiodistal dimensions.

In Group 2, 3mm of gutta-percha were removed from the root canal and cervical sealing was performed with calcium hydroxide PA covered with glass ionomer cement RelyX Luting (3M ESPE, St. Paul, MN, USA)

. A 24\% EDTA gel was applied in the pulp chamber for 3 minutes and washed with distilled water for 1 minute,

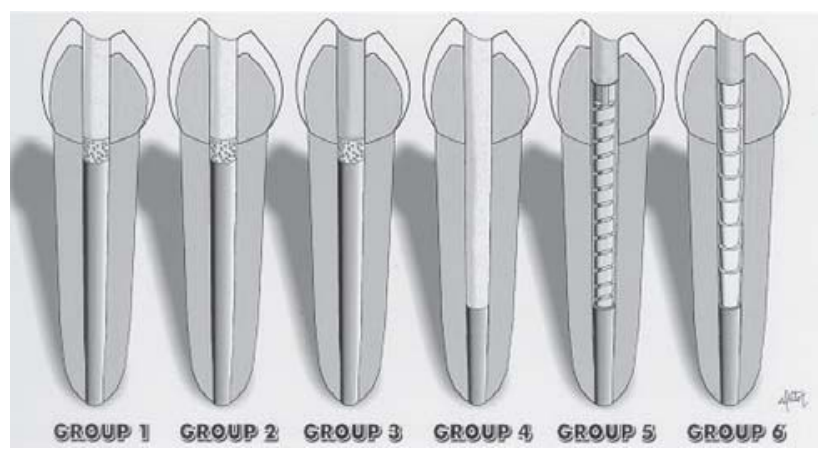

FIGURE 1- Schematic representation of the six groups 
followed by drying with suction, air-drying and absorbent paper. The pulp chamber was filled with 37\% carbamide peroxide gel Whiteness Super-Endo (FGM Produtos, Joinville, SC, Brazil), which was covered with a cotton pellet; the glass ionomer cement Ketac Fil Plus (3M ESPE, St. Paul, MN, USA) was used for provisional sealing and protected with cavity varnish. The specimens were immersed in distilled water at $37^{\circ} \mathrm{C}$ for 7 days, and the bleaching agent was changed after this period. At 14 and 21 days the bleaching agent was changed again. After completion of bleaching, the pulp chamber was sealed with IRM as in Group 1, allowing evaluation of the resistance and fracture pattern of bleached teeth temporarily sealed with a non-adhesive material (stage previous to definitive restoration of the bleached tooth) and also allowing comparison with Group 1 (without bleaching).

In Group 3, bleaching was performed as for Group 2. Afterwards, the bleaching agent was removed with distilled water and the pulp chamber was filled with a paste of calcium hydroxide PA and distilled water for neutralization of the bleaching material. After 7 days, the pulp chamber was opened, washed and and dried with suction and absorbent paper to change the paste. At 14 days, the paste was removed and acid etching was performed with 37\% phosphoric acid for 30 seconds, followed by rinsing with distilled water for 60 seconds and drying with an endodontic canula and absorbent paper. The adhesive system employed was Scotchbond Multi-Purpose Plus (3M ESPE, ST. Paul, MN, USA). The primer of the system was applied for 10 seconds with a Microbrush applicator, followed by gentle air-drying for 3 seconds. Then, the adhesive was applied and light cured (XL 2500, 3M ESPE, ST. Paul, MN, USA) for 20 seconds. The pulp chamber was sealed with composite resin Filtek Z250 (3M ESPE, St. Paul, MN, USA), applied with a Centrix syringe in 2-mm increments, light cured for 10 seconds through the tooth structure and for 50 seconds on the occlusal aspect. The last increment was light cured for 60 seconds on the occlusal aspect. Finishing and polishing were performed as usual.

In Group 4, after bleaching, the root canals were prepared at 10-mm depth with a Largo bur n. 4 (Dentsply Maillefer, Ballagues, Switzerland). The root canal and pulp chamber were filled with IRM. This group allowed evaluation of the influence of root canal preparation on tooth weakening (fracture resistance) and failure pattern of specimens. Thus, the root canal and pulp chamber were filled with a nonadhesive material (IRM) to avoid internal reinforcement of the specimens, which might occur if the teeth were filled with adhesive materials.

In Group 5, after bleaching, neutralization of the bleaching agent and root canal preparation as for Group 4. Then, a stainless steel post (Reforpost n. 2, Odonto-Lógika Ltda, PA, Brazil) was luted in the root canal with zinc phosphate cement (S. S. White Artigos Dentários, RJ, Brazil), keeping a 2-mm space above the post for the composite resin. Before luting, the root canals were washed with distilled water and dried with suction and paper points, and the posts were blasted with aluminum oxide $(50 \mu \mathrm{m})$. After preparation of the cement following ADA specification n. 8, the cement was applied in the root canal with a lentulo spiral. The post was inserted under finger pressure and submitted to a 5-kg static load for 10 minutes. Filling with composite resin was performed as for Group 3.

Group 6 was submitted to bleaching, neutralization and root canal preparation as for Group 4. The root canal was prepared at $10-\mathrm{mm}$ depth using the bur provided by the manufacturer of glass fiber posts FibreKor n 2 (Pentron Corporation, Wallingford, Connecticut, USA). The bur diameter (1.25-mm diameter) corresponded to that of the posts, which are cylindrical and have mechanical retentions throughout their extension. Luting was performed with the dual cure resin cement RelyX CRA (3M ESPE, St. Paul, MN, USA), keeping a 2-mm space for the composite resin. After acid etching as for Group 3, rinsing was performed with distilled water for 60 seconds, followed by drying with endodontic canula and absorbent paper points. Then, the adhesive system Scotchbond Multi-Purpose Plus (3M ESPE, St. Paul, MN, USA) was applied on the root canal walls, following the manufacturer's recommendations for achievement of dual curing. The posts were cleaned with ethyl alcohol and silane (Scotchbond Ceramic Primer, 3M ESPE, ST. Paul, MN, USA) was applied on the posts for 1 minute, followed by air-drying and application of the catalyst of the adhesive system Scotchbond Multi-Purpose Plus. The resin cement was inserted in the root canal with a lentulo spiral, and the post was inserted with digital pressure and kept under a 5-kg static load for 6 minutes. Light curing was performed for 60 seconds on the occlusal aspect, and the restoration was performed with composite resin as for Group 3.

The specimens were kept in distilled water at $37^{\circ} \mathrm{C}$ for 24 hours before axial compressive fracture strength testing, which was performed in a universal testing machine (model K-2000MP, Dinamômetros Kratos Ltda., São Paulo, Brazil), at a crosshead speed of $0.5 \mathrm{~mm} / \mathrm{min}$. Load was applied with a cylindrical bur contacting the cusp inclines. The fracture strength values were submitted to one-way analysis of variance, at a significance level of $5 \%$.

The fracture mode was analyzed with aid of a magnifying glass (4 magnifications) and classified as: 1) fracture of cusp tip and/or marginal ridge; 2) partial fracture of cusp and/or marginal ridge up to the middle third; 3 ) complete fracture of one cusp and/or marginal ridge, not surpassing the cementoenamel junction; 4) complete fracture of one cusp, surpassing the cementoenamel junction; 5) fracture of the entire crown. Fractures type 1, 2 and 3 were regarded as favorable, and types 4 and 5 were considered unfavorable.

\section{RESULTS}

Table 1 and Figure 2 present the mean compressive strength values and standard deviation for the 6 groups. The one-way analysis of variance did not reveal statistically significant difference between the 4 groups $(p<0.05)$. Group 6 presented the highest fracture resistance value (60.12kgf) 
and Group 4 exhibited the lowest value (45.727kgf); intermediate values were observed for the other groups.

Table 2 and Figure 3 display the failure pattern of each group. The most unfavorable failure patterns were observed for groups 2, 4 and 5, which presented 50\%, $40 \%$ and $30 \%$ of unfavorable failures, respectively. The most favorable failure patterns were found for groups 6 and 3, both with $80 \%$ of favorable failures.

Figures 4 to 8 demonstrate the five fracture patterns most commonly observed in the specimens.

\section{DISCUSSION}

Several studies have observed strength reduction or dental alterations after bleaching ${ }^{13,5,20,9,12,18,8,10,23}$, even though it cannot be stated that microstructural changes reduce the tooth strength to a clinically important level, whereas others did not observe reduced strength or structural alterations with bleaching $21,27,17,11,29$, increasing the controversy as to the effects of bleaching on the dental tissues. It has also been stated that the reduction in dentin microhardness after bleaching is not clinically significantly harmful, since a less hard tooth has a higher coefficient of elasticity, which makes it less friable and thus more resistant to fracture ${ }^{27}$, being that remineralization of the enamel occasionally affected by

TABLE 1- Mean compressive strength (in kgf) and standard deviations for the 6 study groups

\begin{tabular}{lll}
\hline GROUPS & MEAN (kgf) & STANDARD DEVIATION \\
\hline 1 & 56.23 & 10.90 \\
2 & 48.96 & 9.34 \\
3 & 53.99 & 11.97 \\
4 & 45.72 & 10.16 \\
5 & 54.22 & 12.65 \\
6 & 60.12 & 19.00 \\
\hline
\end{tabular}

bleaching is possible by utilization of concentrated fluoride solutions ${ }^{18}$ or even by the remineralization capacity of saliva $^{20}$

In case there is reduced strength, it does not imply in tooth fracture, as demonstrated in a study ${ }^{14}$ comprising follow-up of teeth bleached and restored with composite resin and a post for 3 to 16 years, which revealed a low incidence of fracture. The strength lost may be partially recovered by restoration with adequate materials, avoiding later occurrence of fractures; a composite resin restoration allows achievement of strength close to that of intact teeth submitted to similar preparation ${ }^{3,7}$.

There was no statistically significant difference between

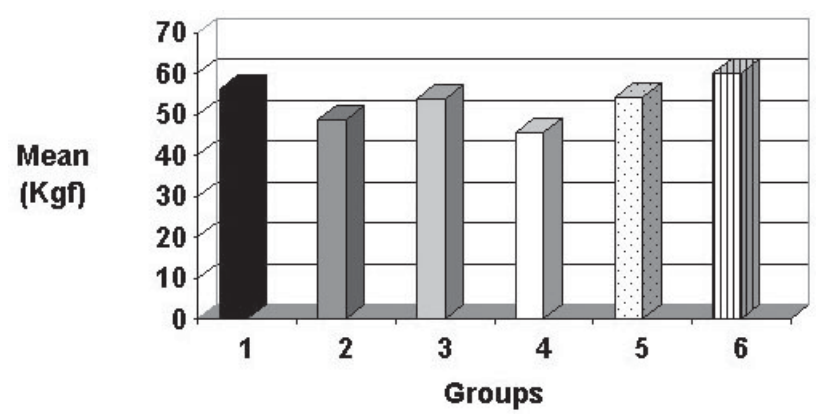

FIGURE 2- Graph representing the mean fracture strength values of the study groups

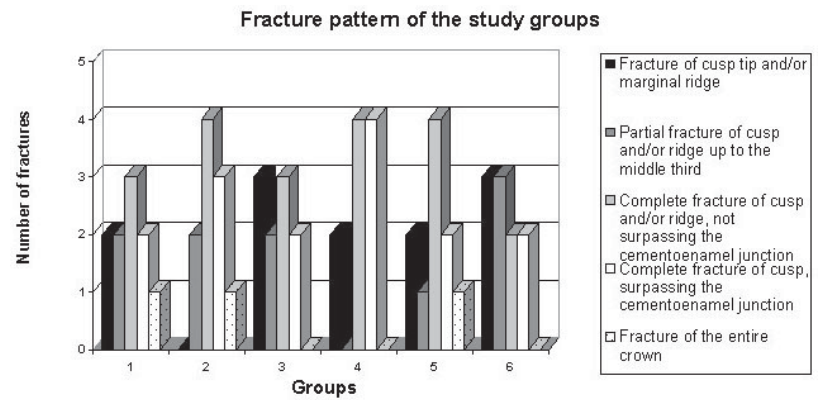

FIGURE 3- Graph representing the fracture pattern of the study groups

TABLE 2- Failure pattern observed for each study group

\begin{tabular}{|c|c|c|c|c|c|c|}
\hline FAILUREPATTERN & $\begin{array}{l}\text { GROUP } 1 \\
(n=10)\end{array}$ & $\begin{array}{l}\text { GROUP } 2 \\
(n=10)\end{array}$ & $\begin{array}{l}\text { GROUP } 3 \\
(n=10)\end{array}$ & $\begin{array}{l}\text { GROUP } 4 \\
(n=10)\end{array}$ & $\begin{array}{l}\text { GROUP } 5 \\
(n=10)\end{array}$ & $\begin{array}{l}\text { GROUP } 6 \\
(n=10)\end{array}$ \\
\hline $\begin{array}{l}\text { Fracture of cusp tip } \\
\text { and/or marginal ridge }\end{array}$ & $2(20 \%)$ & - & $3(30 \%)$ & $2(20 \%)$ & $2(20 \%)$ & $3(30 \%)$ \\
\hline $\begin{array}{l}\text { Partial fracture of cusp tip and/ } \\
\text { or marginal ridge up to the } \\
\text { middle third }\end{array}$ & $2(20 \%)$ & $2(20 \%)$ & $2(20 \%)$ & - & $1(10 \%)$ & $3(30 \%)$ \\
\hline $\begin{array}{l}\text { Complete fracture of cusp tip and/ } \\
\text { or marginal ridge, not surpassing } \\
\text { the cementoenamel junction }\end{array}$ & $3(30 \%)$ & $4(40 \%)$ & $3(30 \%)$ & $4(40 \%)$ & $4(50 \%)$ & $2(20 \%)$ \\
\hline $\begin{array}{l}\text { Complete fracture of one cusp, } \\
\text { surpassing the cementoenamel } \\
\text { junction }\end{array}$ & $2(20 \%)$ & $3(30 \%)$ & $2(20 \%)$ & $4(40 \%)$ & $2(20 \%)$ & $2(20 \%)$ \\
\hline Fracture of the entire crown & $1(10 \%)$ & $1(10 \%)$ & $\ldots$ & $\ldots$ & $1(10 \%)$ & - \\
\hline
\end{tabular}


the different groups with regard to the techniques employed in the present study (technique of coronal opening, root canal preparation, and number of applications of bleaching agent performed). Comparison between Group 1 (without bleaching) and Group 2 (with bleaching) reveals that bleaching with $37 \%$ carbamide peroxide did not reduce the fracture strength, even though there may have been alterations in the dental microstructure. Several studies ${ }^{13,4,7}$ revealed strength reduction of 17 to $53 \%$ when sodium perborate was associated with superoxol, suggesting that $37 \%$ carbamide peroxide is less aggressive to the tooth structure.

It should be considered that, despite the lack of
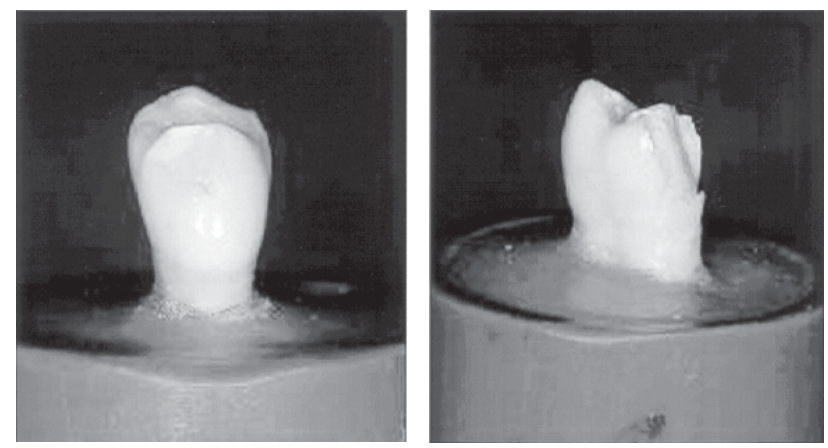

FIGURE 4- Fracture of cusp tip and/or marginal ridge
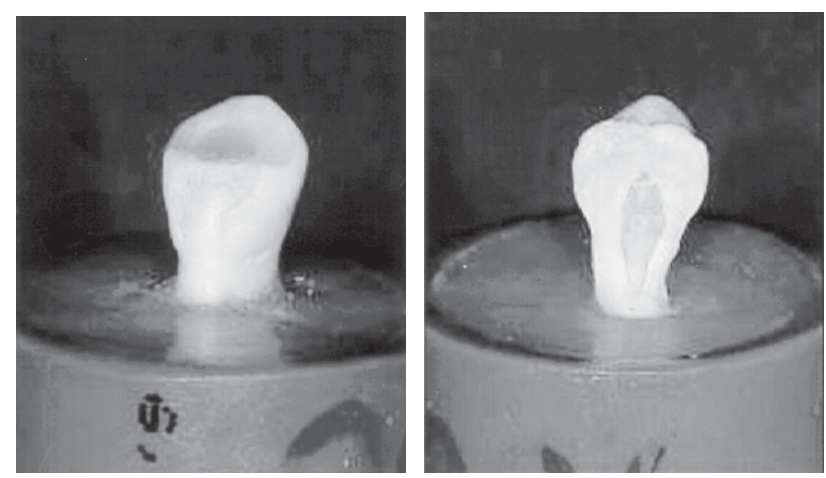

FIGURE 6- Complete fracture FIGURE 7-Complete fracture of cusp and/or marginal of cusp, surpassing the ridge, not surpassing the cementoenamel junction cementoenamel junction

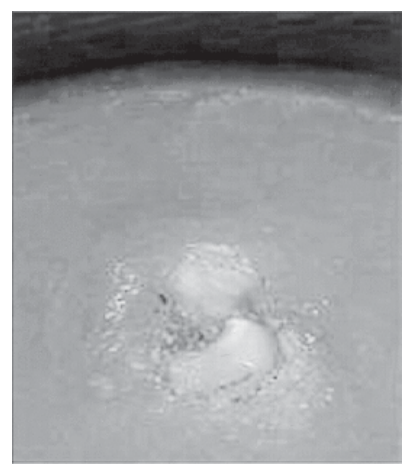

FIGURE 8- Fracture of the entire tooth crown statistical difference between the study groups, there were numerical differences between groups, which were more remarkable between Groups 4 (45.72kgf) and 6 (60.12kgf). The latter revealed adhesion of all restorative materials to the dental tissues, yielding a biomechanical complex able to reinforce the remaining tooth structure, as also observed in a previous study ${ }^{7}$. Group 4 exhibited the lowest strength among all groups and a very unfavorable fracture pattern, indicating that the prepared root canal should not be left empty, and utilization of the treated tooth during the stage of provisional restoration should be limited.

The largest number of unfavorable fractures was found for Groups 2 (50\%), 4 (40\%), and 5 (30\%), whereas Group 6 exhibited the most favorable failure pattern, followed by Groups 3 and 1 (Tab. 2). The metallic posts used in Group 5 did not prevent unfavorable fractures, yet the highly favorable failure pattern in Group 6 demonstrated that the glass fiber post luted with adhesive cement may be well indicated.

Composite resin restoration, even when not associated to the glass fiber post, provided a low number of unfavorable fractures, suggesting that this material reduces the risk of fractures, especially those that would lead to tooth extraction (also called catastrophic) by promotion of internal involvement of the tooth structure by adhesion to the cavity walls, allowing partial recovery of the strength lost during coronal opening and occasionally during bleaching. The results of the present study indicated that adhesion of composite resin was not affected, even though other studies have mentioned that bleaching reduces the adhesion ${ }^{12,1,26}$. In the present study, a 14-day period was expected before restoration, to allow oxygen release to avoid interference with adhesion ${ }^{12,26}$.

It should also be remembered that, if the bleached tooth presents loss of marginal ridges due to preexisting carious lesions, there is a significant decrease in strength. Maxillary canines bleached with sodium perborate and superoxol for 21 days were divided into 4 groups: 1) only coronal opening; 2) coronal opening and bleaching; 3) coronal opening, removal of one marginal ridge and bleaching; 4) coronal opening, removal of two marginal ridges and bleaching, being that group 1 presented higher compressive strength, followed by Groups 2, 3 and 4, respectively ${ }^{4}$.

The results achieved in this study suggest that internal bleaching with $37 \%$ carbamide peroxide did not cause significant weakening of the tooth structure, and that composite resin, associated or not with the glass fiber post, protected the specimens against unfavorable fractures. Coronal opening and removal of the pulp chamber roof probably contribute more to the strength reduction than bleaching itself ${ }^{27}$. However, extrapolation of the results of in vitro studies to the clinical situation should be careful, since it is impossible to state that no bleaching technique reduces the tooth strength. Nevertheless, even if such reduction occurs, other options for the treatment of tooth discolorations, as full crowns or laminate veneers, involve higher strength reduction due to the large removal of tooth structure. 


\section{CONCLUSIONS}

1. There were no significant differences in fracture resistance between the 6 groups.

2. Among the bleached teeth (groups 2 to 6 ), the most unfavorable fracture pattern was observed for groups with temporary fillings (IRM) of restored with metallic posts, whereas the most favorable failure pattern occurred for specimens restored with adhesive materials (composite resin and glass fiber posts).

\section{REFERENCES}

1- Attin T, Hanning C, Wiegand A, Attin R. Effect of bleaching on restorative materials and restorations - a systematic review. Dent Mater 2004;20:852-61.

2- Baratieri LN, Maia E, Andrade MAC, Araújo E. Clareamento dental. São Paulo: Ed. Santos; 1993.

3- Bezerra RB. Avaliação da resistência à fratura de caninos superiores, hígidos, preparados, branqueados e restaurados por diferentes técnicas e materiais restauradores. São Paulo; 1998. (Tese de Doutorado Faculdade de Odontologia da Universidade de São Paulo).

4- Bezerra RB. Influência das cristas marginais na resistência à fratura de dentes despolpados submetidos ao tratamento clareador. Bauru; 1993. (Dissertação de Mestrado - Faculdade de Odontologia de Bauru, Universidade de São Paulo)

5- Bitter NC. A scanning electron microscopy study of the effect of bleaching agents on enamel: a preliminary report. J Prosthet Dent. 1992; 67:852-5.

6- Cara AA. Estudo in vitro da influência do clareamento dental e de duas técnicas restauradoras adesivas na resistência à compressão de dentes tratados endodonticamente. São Paulo; 1996. (Tese de Doutorado - Faculdade de Odontologia da Universidade de São Paulo).

7- Cara AA, Capp CI, Shiozawa LJ, Mandetta S. Influência do clareamento dental e de duas técnicas restauradoras adesivas na resistência de dentes tratados endodoticamente. Rev Pós-Graduação Fac Odont USP. 1998;5:152-60.

8- Cavalli V, Arrais CA, Giannini M, Ambrosano GM. Highconcentrated carbamide peroxide bleaching agents effects on enamel surface. J Oral Rehab. 2004;31:155-9.

9- Chng HK, Palamara JEA, Messer HH. Effect of hydrogen peroxide and sodium perborate on biomechanical properties of human dentin. J Endod. 2002;28:62-7

10- Chng Hk, Yap AU, Wattanapayungkul P, Sim CP. Effect of traditional and alternative intracoronal bleaching agents on microhardness of human dentine. J Oral Rehab. 2004;31:811-6.

11- Cvitko E, Denehy GE, Swift EJ Jr., Pires JA. Bond strength of composite resin to enamel bleached with carbamide peroxide. J Esthet Dent. 1991;3:100-2.

12- Dahl JE, Pallesen U. Toot bleaching - a critical review of the biological aspects. Crit Rev Oral Biol Med 2003;14:292-304.

13- Francischone CE, Francisconi PAS, Oliveira LAF, Coradazzi JL. Clinical study of dental bleaching: follow up 3 to 16 years. J Dent Res. 1990;69:929.
14- Francischone CE, Francisconi PAS, Souza Junior MHS, Mondelli J, Ishikiriama A. Resistência à fratura de dentes despolpados tratados com agentes clareadores. Rev Bras Odontol. 1986;43:2-5.

15- Fuss Z, Lustig J, Katz A, Tamse A. An evaluation of endodontically treated vertical root fractures teeeth : impact of operative procedures. J Endod. 2001;27:46-8.

16- Grossman LI. Endodontic Practice. Philadelphia: Lea \& Febiger; 1981.

17- Haywood VB, Leech T, Heymann HO, Crumpler D, Bruggers K. Nightguard vital bleaching: Effects on enamel surface texture and diffusion. Quintessence Int. 1990;21:801-4.

18- Lewistein I, Fuhrer N, Churaru N, Cardash H. Effect of different peroxide bleaching regimens and subsequent fluoridation on the hardness of human enamel and dentin. J Prosthet Dent. 2004;92: 337-42.

19- Lim, KC. Considerations in intracoronal bleaching. Aust Endod J. 2004;30:69-73.

20- McCracken MS, Haywood VB. Effects of 10\% carbamide peroxide on the subsurface hardness of enamel. Quintessence Int. 1995;26:214

21- Moraes SH, Aragão EM, Heck AR, Moraes CAH. Resistência à fratura em dentes despolpados e clareados. Rev Gaúcha Odont. 1991; 39:309-10.

22- Pinheiro Junior EC, Fidel RA, da Cruz Filho AM, Silva RG, Pecora JD. In vitro action of various carbamide peroxide gel bleaching agents on the microhardness of human enamel. Braz Dent J. 1996;7:75-9.

23- Pinto Cf, De Oliveira R, Cavalli V, Giannini M. Peroxide bleaching agent effects on enamel surfaces microhardness, roughness and morphology. Pesqui Odontol Bras. 2004;18:306-11.

24- Reel DC, Mitchell RJ. Fracture resistance of teeth restored with Class II composite restorations. J Prosthet Dent. 1989;61:177-80.

25- Rotstein I, Dankner E, Goldman A, Heling I, Stabholz A, Zalkind M. Histochemical analysis of dental hard tissues following bleaching. J Endod 1996; 22: 23-6.

26- Shinohara MS, Peris AR, Pimenta LA, Ambrosano GM. Shear bond strength evaluation of composite resin on enamel and dentin after nonvital bleaching. J Esthet Restor Dent. 2005;17:22-9.

27- Siqueira EL, Santos M, Di Girolamo Neto JA, Santos FLHV. Resistência ao cisalhamento de dentes submetidos a duas técnicas de clareamento, pós-restaurados ou não. Rev Odont USP. 1997;11 suppl:15-9

28- Torneck CD, Titley KC, Smith DC, Adbifar A. The influence of the time of peroxide in the adesion of composite resin to bleached bovine enamel. J Endod. 1990;16:123-8.

29- Worchech CC, Rodrigues JA, Martins LR, Ambrosano GM. In vitro evaluation of human dental enamel surface roughness bleached with 35\% carbamide peroxide and submitted to abrasive dentifrice brushing. Pesqui Odontol Bras. 2003,17:42-8. 